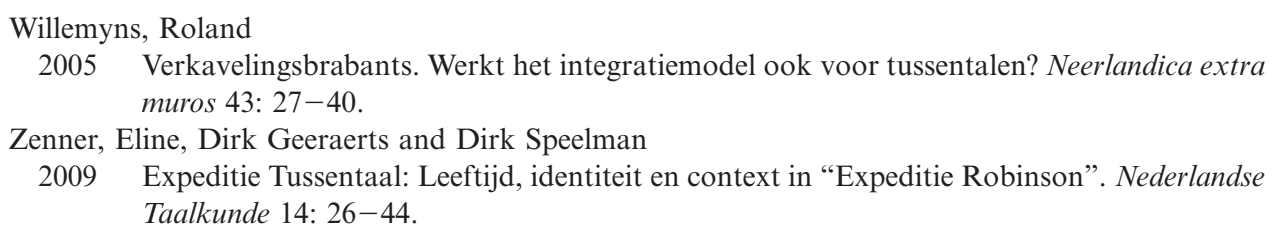

\title{
29. Non-standard varieties in the new media
}

\author{
1. Introduction \\ 2. Overview of the data \\ 3. Conclusions and perspectives \\ 4. References
}

\section{Introduction}

Computer-mediated communication $(\mathrm{cmc})$ is a cover term for relatively new forms of (written) communication which use machines that have computer chips, ranging from desktop computers with an internet connection to mobile phones with texting facilities. The range of cmc applications currently in use is rather large, varying from e-mail (which allows for 'letters' of arbitrary length to be sent, including complete text documents, pictures and any other computer files) using social network sites (which allow day to day communication with groups of 'friends' or 'followers', usually in a rather compact form) to chatting (exchanging short messages in real time on a computer network) and texting (doing something similar using the phone line). At the same time, we also see convergence of these different media: big companies like Google and Facebook offer applications that blur the boundaries between these different genres.

Some people believe that these new media have a very strong impact on languages in the modern world. Many of these people will typically regard this influence as a negative one. In a 2004 online questionnaire of the Dutch magazine Onze Taal ('Our Language', a journal aiming at an audience of 'language lovers') $66.6 \%$ of the voters (623 out of 936) believed that texting would lead to 'deterioration' of the Dutch language. Two years later, Dutch newspapers announced that the use of 'texting language' would be disallowed in some schools (Spooren 2011). It should be pointed out, however, that the tone of popular publications about the topic is not always concerned or scornful. Many articles in the popular press describe texting language, in particular, as an amusing and playful new variety (Sanders 2001, Daniëls 2001, 2002, 2009, Van Wijk and den Ouden 2006, Van Oostendorp 2003). 
Given the concerns of the average speaker, it is rather remarkable that so far little serious research has been done on the topic of language in the new media. In particular, the amount of work published in journals or books is limited (as far as the situation in the Netherlands and Flanders is concerned; I have not been able to find anything written in any language other than Dutch), although several BA and MA theses have been written on the topic, both in Belgium and the Netherlands. (Interestingly, the only $\mathrm{PhD}$ thesis produced on cmc language deals with the situation in Kenya, viz. Barasa 2010). For this reason I will rely on a number of rather unusual sources at some points in this Chapter.

One reason for the discrepancy between the attitudes of the public and the interest by researchers may be that the latter do not seem to share the worries of the former. Indeed, several studies have shown that there is no reason to believe that the rise of new media genres has a negative effect on other types of language. We will discuss this below.

Another reason may be that data from the new media are not always easy to collect. This may be somewhat surprising at first, since by definition, computer-mediated communication data are in digital format and therefore can easily be stored and easily searched. Yet at least two connected problems arise.

In the first place, many of the data channels are private in one way or another. This is most clearly the case for texting, which relatively many studies have focused on. Many mobile phones used not to allow transfer of text messages from phone to computer other than by copying them by hand - a method which makes it time-consuming to collect data on a large scale, also because not many people would allow a researcher access to their private mobile phone. This technical problem will become less urgent since more and more smartphones (i.e. mobile phones with strong internal computer facilities and an internet connection) allow users to back up texts to external media, such as the harddrive of a computer.

The problem also arises for other genres. For instance, Facebook $(<$ http://www. facebook.com/ $>$ ), which is currently without any doubt the most popular social network site, allows access to a user's data only for that user's "friends" (the people who have been given explicit consent to access these data). This means that it is difficult to gather data outside the researcher's own peer group, let alone do the kind of large-scale data mining which such sites, with hundreds of millions of users, would otherwise make possible.

Other social network sites, such as Twitter (<http://www.twitter.com $>)$, are more 'open' and therefore potentially more attractive to researchers, but I am not aware of any studies involving Dutch or Flemish twitter users.

A second problem that arises will be familiar to students of informal, 'spontaneous' speech in general and is related to the linguistic status of the data themselves, which are often informal and personal. This causes, first, problems with privacy laws, but, secondly, also with interpretation. The specific codes connected to media usage which are of such great concern to the layman are often of a very personal and intimate nature: the in-group in which a code is used may not be larger than the sender and receiver of the message. This becomes problematic in combination with the large amount of data: the opacity of the transmitted code invites qualitative rather than quantitative study.

This chapter aims to show that language use in the new media deserves attention from anybody who is seriously interested in language variation. The data offer an interesting new window on, among other things, the way in which people are aware of and 
manipulate different text genres, formal properties of grammatical structure, and the way in which people use language forms to express and manipulate identity. In section 2 I will consider some of the specific issues that come up in this particular type of research, as it is known for other languages (e.g. Androutsopoulos 2010a, b, Bodomo 2009). Section 3 presents conclusions and an outlook on some perspectives.

\section{Overview of the data}

\subsection{Genres}

First, I will discuss studies on genre, both those comparing new media to other types of language use, and comparing them to each other. I have already noted that some people seem worried by the effect that language use in new media may have on language use in other (more formal) contexts. One such worry is that children will no longer be able to use formal language in, for instance, official letters or school tests.

One of the few studies we have at present regarding this issue in Dutch is Spooren (2009) (see also Spooren 2011). This study consists of two parts. First, Spooren (2009) did a survey with a group of young students of Dutch high schools between 15 and 17 years old, their teachers and their parents (112 students, 77 teachers and 74 parents participated). He asked them to score their reaction to the five statements in (1) on a 5 point Likert scale:

(1) a. Chatting makes me spell better.

b. Chatting makes me write better.

c. Chatting makes me write more often.

d. Chatting makes me more creative while writing.

e. Chatting makes writing easier for me.

It turned out that there were statistically significant differences between the three groups (of students, teachers and parents) for (the first) four out of five of these statements.

Generally speaking, parents seem to be the most 'pessimistic' about the influence of chats on other language skills. According to Spooren (2009), they worry in particular about the quality of spelling and the quality of the texts. Teachers were the most 'optimistic', and the students were in between. Although Spooren (2009) does not comment on this aspect, it seems to me that these results also indicate that there are no widespread

Tab. 29.1. Judgements about the relationship between chatting and writing capacities $(1=$ max. negative, $5=$ max. positive; standard deviation in parentheses)

\begin{tabular}{lccc}
\hline & Students $(n=112)$ & Teachers $(n=77)$ & Parents $(n=74)$ \\
\hline a. Better spelling & $2.95(1.19)$ & $3.69(0.97)$ & $2.26(1.03)$ \\
b. Write better text & $3.41(1.15)$ & $3.30(1.06)$ & $2.66(1.14)$ \\
c. Write more often & $2.54(1.19)$ & $2.99(1.11)$ & $2.74(1.15)$ \\
d. Write more creatively & $2.79(1.13)$ & $2.78(0.87)$ & $3.08(1.07)$ \\
e. Write more easily & $2.49(1.16)$ & $3.26(0.91)$ & $2.78(1.09)$ \\
\hline
\end{tabular}


worries about chatting: most of the means in this table are above 2.5 - the midpoint between being negative and being positive. Furthermore, people seem to be particularly positive about the effects on the quality of the products: the average scores are highest on the questions about the quality of spelling and that of text production (questions a andb), although it is difficult to determine whether this effect is significant without investigating Spooren's original data.

The second part of Spooren's (2009) study was a standard writing test, applied to a number of groups of secondary school students. These tests were evaluated on a number of aspects such as coherence, adherence to a few well-established norms of SD, etc. Furthermore, the students filled in a questionnaire on their use of new media as well as on their appreciation of the 'Dutch language' course in school. This test showed that there was no statistically significant correlation between reported active use of new media and scores on the standardized test, even though the latter did correlate positively with other variables, such as the question on 'Dutch language' as a school course.

Grondelaers et al. (2001) compare language use in the new media to that in other media in a very different way. (As an aside, I should mention that Grondelaers et al. 2001 call the spelling of chats 'appalling' at some point in their article, showing that at least some researchers have a negative view of certain aspects of language use in the new media.) In this relatively early study, word use in IRC (internet relay chat, one of the earlier forms of group chatting technology) and Usenet (internet groups on which people communicate by the equivalents of e-mail messages) are compared to those of other sources. The focus of the study is on the question whether the standard languages of Flanders and the Netherlands are converging or diverging from the point of view of the lexicon, in particular in words referring to garments. Grondelaers et al. found, among other things, that there is more divergence between the two countries in IRC than in Usenet, and more in Usenet than in a (printed) newspaper corpus. This is attributed to the relative formality of the several genres. At the same time, Grondelaers et al. observe that "the informality of IRC does not seem to be determined in the first place by lexical factors. No matter how idiom-prone and abusive IRC-users may be, the high uniformity between IRC and the newspapers suggests that chatters tend to be quite conformist when referring to everyday concepts such as clothing."

\subsection{Formal aspects}

A second aspect that has occasionally been studied is formal: which are the properties of new media language which distinguish it from other types of language use, and how can these properties be understood? On the one hand, the language used in the new media has certain characteristics of written language, but at the same time it seems to contain an unusually large number of colloquialisms, and typically a mixture of informal standard language, dialect and (youth) slang. These were traditionally assumed to be more characteristic of spoken language, and it therefore has become a topos of talk on new media language use to say that it is 'more like spoken language'.

A third feature, contradicting the previous one, is that new media language use is playful with spelling conventions: words are abbreviated (sometimes also because short messages are cheaper to send and quicker to compose), numbers are used instead of letters, etc. 
I am not aware of any published work on the specifics of standard or non-standard Dutch in the new media, but there are several undergraduate theses written at Dutch and Flemish universities; the picture they offer does not seem very different from what we know about English (see e.g. Crystal 2008).

A particularly good overview is provided by an MA Thesis by Willems (2009), based on a corpus of 518 text messages, sent by 175 people between 12 and 40 years old, mostly from Willems' own social circle in East Flanders. She distinguishes a rather large number of variable phenomena which can roughly be divided into two groups: features that are typical of 'everyday spoken language' mostly referring to features that distinguish the dialect or 'tussentaal' (see Geeraerts and Van de Velde, Ch. 28 in this volume) from the written standard ((2) gives a selection; see Chapters 12 (Taeldeman) and 13 (De Vogelaer) for more on the phonology and morphosyntax of East Flemish), and on the other hand certain features which are specific for text messages (3).

(2) Spoken language features

a. h-procope: ier 'here' (instead of hier)

b. apocope and syncope in function words: wa 'what' (instead of wat), as 'if' (instead of als)

c. deletion of $-n$ or $-e$ in words ending in $-e n$ : denkeldenkn 'think' (instead of denken)

d. proclisis and enclisis: kheb 'I have' (instead of $i k$ heb), ist 'is it' (instead of is het), kunde gij 'can you' (instead of kun jij. The ending -de is interpreted as an enclitic here; notice that it is followed by a full pronoun, which is also nonstandard; see De Vogelaer 2008)

e. agreement of adnominal elements: nen gelukkigen verjaardag 'a happy birthday' (SD would have een gelukkige verjaardag, with no ending on the determiner and no masculine ending on the adjective; notice that the 'traditional' dialect would not have an $n$ here either, since it is restricted to contexts in which a following word starts with a vowel, $t, d$ or $b$, as Johan Taeldeman, p.c., points out)

f. auxiliary gaan 'go': Kdenk ni dak mrgn ga gaan, ma kweetet nog ni. 'I think I will not go [litt: go not go] tomorrow, but I don't know yet'.

g. Topic drop: Ben zaterdagavond in Geel '[I] will be in Geel on Saturday evening' (most examples are like this in that the dropped topic is also a subject).

(3) Features specific for texting and chatting

a. acronyms: Zjg 'I like you' (instead of [ik] zie je graag)

b. abbreviations: leaving out vowels and consonants within a word ( $l k k r$ instead of lekker 'good')

c. CU category: the names of letters should be read aloud (cu $=$ see you; $\mathrm{ff}=$ effen 'for a while')

d. number spelling: w8 'weight'(wacht), suc6 'success' (succes)

e. letters spelt differently: this typically involves spelling orthographically correct digraphs with single letters having more or less the same value: $m y$ 'me' (mij), sgool 'school' (school)

f. symbols: \& 'and' (en), $x$ 'times'(keer) 
Willems (2009) shows that the phenomena in (2) and (3) tend to be more widely used in her corpus, and generally her younger informants use them more frequently than the older group. This is true in particular for the phenomena in (3), which were specific for texting language. Furthermore, Willems' statistical analyses show that the younger people in her sample tend to apply the special characteristics in each of (2) and (3) significantly less frequently in texts sent to adults (parents and other relatives, teachers, etc.) than in texts sent to their peers, demonstrating once again that they are aware of the differences between audiences.

One dialect phenomenon invites further comment. In a large part of the Dutch language area (including economically and culturally dominant regions such as Holland and Antwerp) the $-n$ is regularly dropped after schwa (Van Hout and Van de Velde 2000). Yet in certain regions, including especially West Flanders, it is the schwa that is dropped. In their West Flemish texting corpus, Vandekerckhove and Nobels (2009) find both phonological operations reflected in the spelling of a corpus of 15 male and 38 female chatters (age range between 13 and 20 years old, all born in West Flanders), albeit to different degrees:

\begin{tabular}{|c|c|}
\hline 4) $n=3891$ & $\%$ \\
\hline$<\mathrm{en}>$ & 50,69 \\
\hline$<\mathrm{n}>$ & 45,7 \\
\hline$<\mathrm{e}>$ & 3,59 \\
\hline
\end{tabular}

It is interesting that Willems' (2009) results on this topic are different. In her corpus of text messages sent by students between 12 and 18 years old, $<\mathrm{e}>$ was found in $36 \%$ of the cases and $<\mathrm{n}>$ in $18 \%$ of the cases. The difference may be due to a dialect difference between West Flanders (Vandekerckhove and Nobels) and East Flanders (Willems), or, more likely, to a difference in dialect loss in the two regions, as Taeldeman (p.c.) has pointed out to me. This is then reflected in an interesting way in the differences in the statistical distribution of the non-standard variants between the two areas.

Bennis $(2007,2008)$ points out that $(3 \mathrm{~b})$ might be a new media-specific phenomenon that is interesting from the point of view of grammatical theory. He introduces the onset principle, formulated in algorithmic terms:

(5) Onset principle

- move from left to right until the end of the onset of the first syllable (onset: sch-aak 'chess', spr-aak 'speech', kr-aak 'crack', $k$-aak 'jaw').

- the onset should not be empty

- move until the end of the onset of the next syllable if necessary/desired

- degeminate double consonants at the end of an abbreviation

Bennis $(2007,2008)$ observes that in this way a word such as vanzelfsprekend 'self-evident, natural' can be abbreviated to v., vanz., vanzelfspr. and vanzelfsprek. Bennis (2007, 2008) also mentions a few "subsidiary principles", which would be applicable if applying the onset principle would lead to an ambiguous result:

(6) a. Consonant principle: Give all the consonants of the word $(z k t=z o e k t$, 'searches'). 
b. First-and-last: Give the first and last segment of the word ( $n r=$ nummer $)$.

c. Onset only: Give only the onsets of every syllable in the word $(d g l=$ dergelijke 'such')

Although Bennis (2008) does not explicitly point this out, the consonantal principle of course shows a striking resemblance to the spelling system of e.g. Semitic languages. Bennis points out that the fact that language users apply principles such as these (rather than deleting segments randomly or by frequency or some other criterion) provides evidence that language users possess "subconscious knowledge of the structure of the syllable", a notion of linguistic theory.

\subsection{Stylization and identity-marking}

The study of new media language offers interesting new possibilities for using language as an identity marker (of which the work of Androutsopoulos, e.g. 2010ab, is probably the most well-known example). The work done on this topic within the Dutch language area concentrates on the use of dialect features in texting, and the use of texting language in advertisements.

One interesting aspect is that the world-wide web and other new media seem to invite a turn away from the use of standard language and towards other varieties, including regional ones (see also Van Oostendorp 2003). An interesting paper on "destandardisation and appropriation of written culture" is Vandekerckhove and Nobels (2009). This study is based on a corpus of chats (see the previous section). In a qualitative analysis of this corpus, these authors show that there are clear signs that chatters consciously switch between different registers.

The text in (7) gives a simple example of code switching. It starts with a SD expression (denk eens na 'think well'; the West Flemish expression for 'think' is pei( $n)$ zen). After this, the language changes to something closer to a West Flemish basilect, with lexical forms such as bedde=bed ('bed') and $u p=o p$ ('on'), $t$-less forms such as wa =wat ('what') and $d a=d a t$ ('that'), a doubly filled complementizer ( wa tha 'what that') and a West Flemish discourse particle wi.

(7) dus denk eens na in jou bedde wa da je zal schrijven en schrijf da I keer up en da is wel goe wi

so think well in your bed what you would want to write, and write that down in 1 go and that is quite good, you know

The function of code switching in (7) might be unclear, but this is not the case in (8). Again this starts in SD (wou 'wanted' would be wilde in the dialect - the latter form would actually also be accepted as standard language) but then switches to something very close to the dialect. However, there is a switch again in the indirectly reported speech, presumably because the chatter had been speaking SD to insist on his rights to work on the computer:

(8) ik wou up de pc, vo tschole, en min zuster zat van die domme spelletjes te speln, ik vragn vriendelijk of ze van de pc wou, da kik min uswerk kon makn, en min ma zei doodleuk da ze zi der up moete bluvn 
I wanted [to work] on the pc, for school, and my sister was playing those stupid games, I asked in a friendly tone whether she would leave the pc, so that I could make my homework, and my mum said simply that she should stay put

Vandekerckhove and Nobels (2009) claim that the function of code switching is even more obvious in an example such as the following (the conversation is in West Flemish, except for A's second turn ('we zijn ...') which is in SD; the discussion is between two girls about their respective relationships):

(9) A: e mjunder ook goe heb ik gehoord and with you [everything is] also alright, I heard

kvind sjiek

I like it

$\mathrm{B}$ : ist waar alle de is it true, well, well

A: we zijn vandaag een half jaar samen we have been together for half a year as of today

B: alle proficiat

Well, congratulations

The switch to SD makes the announcement of the semi-anniversary of A's relationship stand out as a kind of quasi-official statement. A final observation by Vandekerckhove and Nobels (2009) is that English plays only a marginal role in their corpus. The following is the only full utterance in English in their corpus.

\section{(10) change the subject :)}

Another question is how young people in particular perceive the codes of texting and chats when they are used in other genres: what identity message is transferred by using such codes? An interesting perspective on this issue is offered by den Ouden and Van Wijk (2006). In this study, 16-year old secondary school students were presented with different versions of written advertisements about hair gel and a music dvd. These advertisements were manipulated in different ways; one of those manipulations was that some words were rewritten in a 'text' version, e.g. leaving out the vowels (spelling $l k k r$ instead of lekker 'good'). (The other manipulation involved leaving out intensifiers such as fantastisch 'fantastic', which does not concern us here, as it does not seem to be related to cmc.) It turned out that rewriting advertisements on the whole had a negative effect that was statistically significant. In particular in the ad for hair gel, the students found the rewritten texts less attractive and also less convincing. An MA thesis by Wensveen (2010) reports a similar result: an informative website on healthcare that was rewritten in a 'youth style' (involving among other things aspects of 'chat language') was judged less convincing and attractive by young visitors than the original version. All of this indicates that people are aware of the differences between language in the new media and on other platforms, and furthermore, that they associate language use in new media with particular types of messages only. 


\section{Conclusions and perspectives}

The phenomena discussed in this chapter are very recent. Although the literature is not yet very rich, our overview already seems to allow for certain conclusions. In the first place, all available evidence indicates that users of texting and chatting language registers are aware of the differences between the two, and between texting and chatting on the one hand and older, more established verbal communication modes on the other. They are able to adapt their registers to a more adult audience, they codeswitch where appropriate, and they even do not appreciate the register being used in a different context. Furthermore, there are no indications that using these registers influences their other forms of language use in any way. None of these findings may be extremely surprising to a linguistic readership, but the fact that there is clear evidence for these expectations is a valuable result.

We have also seen that the study of language varieties in new media has much more to offer. In particular, language use in the new media tends to move away from the standard in many directions. Seeing what are the limits of this variation can again teach us something about the underlying structures of Dutch in general, and perhaps even about those of human language in general. (An example of this is Bennis' (2010) observation that in abbreviated words in text message, the consonants rather than the vowels stay behind, which ties in nicely with observations about the differences between consonants and vowels known from Semitic languages.) Work on this is very preliminary, but also promising. A second aspect that seems promising is the analysis of code switching and switching between genres in new media use.

A further important aspect of language in the new media is that there is so much of it, and it is all digitized. It therefore allows for large-scale datamining of more informal and creative language varieties than have hitherto played a role in language studies. In the introduction to this Chapter, I pointed out some practical problems which have arisen. Fortunately, an infrastructure for studying these topics is arising. One important initiative is the SoNaR corpus (STEVIN Nederlandstalig Referentiecorpus, 'STEVIN Dutch Reference corpus'), hosted at the INL in Leiden, which has started collecting Dutch language tweets (140 character messages distributed by the social network site Twitter). It is hoped that such initiatives will allow variational linguists to integrate these interesting varieties into their work.

There are still many desiderata for research. First, a medium such as Twitter seems very promising in particular for new types of research. Like Facebook, Hyves, Google+ and other so-called social-network sites, Twitter allows its users to post short messages and links to interesting material on the internet. The advantage of Twitter as compared to other social network sites is that it is more open: material can be accessed more freely by outsiders (the material that is posted on Facebook, for instance, is typically only accessible to people who have been marked as 'friends').

Study of such social networks would open up many new possibilities. For one thing, one could chart the (virtual) social networks of users, since these are listed for each user, and therefore study the mutual influence of those networks and language use (for instance, in order to find out how new words or constructions spread through such networks). Another type of metadata that is automatically added to every tweet sent on Twitter is the date and time when it was released; this makes it possible to study e.g. the relative frequency of words and constructions according to the time of day (Tjong Kim 
Sang 2011). Twitter is sometimes also called a 'microblogging' service - blogs are online diaries in which people write about their concerns. When used appropriately, it can be used to study microvariation and microdiachrony (study of language change at a very small time scale).

Technology aside, there are many questions to be answered. As we have seen above, there is at least some empirical evidence that 'traditional' language variation influences language use in the new media: dialect features are used for a variety of reasons. An obvious question to ask would be whether the influence also works the other way around: whether the existing variation landscape is changing under the influence of the new media. One could imagine, for instance, that the fact that dialects are nowadays used in written form on a rather wide scale might have an effect on their status, or on the range of topics which speakers discuss in their dialect, but empirical studies on this are still missing.

\title{
4. References
}

\author{
Androutsopoulos, Jannis \\ 2010a The study of language and space in media discourse. In: Peter Auer and Jürgen Erich \\ Schmidt (eds.), Language and Space: An International Handbook of Linguistic Variation. \\ Vol. 1, Theory and Methods, 740-758. Berlin, New York: De Gruyter. \\ Androutsopoulos, Jannis \\ 2010b Localising the global on the participatory web. In: Nikolas Coupland (ed.), Handbook of \\ Language and Globalization. Oxford: Blackwell. \\ Barasa, Sandra \\ 2010 Language, mobile phones and Internet: A study of sms texting, email, IM and SNS chats \\ in computer-mediated communication (CMC) in Kenya. Ph.D. thesis, Leiden University. \\ Bennis, Hans \\ 2007 Korterlands. SMS taal en andere korte schrifftalen. Slides. Dag van de Geestesweten- \\ schappen. \\ Bennis, Hans \\ 2008 Is de lettergreep een taalgreep? Nederlandse taalkunde 13(3): 299-304. \\ Bodomo, Adams \\ 2009 Computer-Mediated Communication for Linguistics and Literacy. Technology and Natural \\ Language Education. Hershey, PA: IGI Global. \\ Crystal, David \\ 2008 Txting. The gr8 deb8. Oxford: Oxford University Press. \\ Daniëls, Wim \\ 2001 Van afvrijen tot zwabbergast: retrotaal en SMS-taal onder jongeren. Amsterdam: Bakker. \\ Daniëls, Wim \\ 2002 SMS: teksten, smileys, sites. Houten: Van Holkema \& Warendorf. \\ Daniëls, Wim \\ 2009 Sms \& msn: hoest begonnuh?, hoe sgrijf jut?, ist errug?. Houten: Prisma. \\ De Kesel, Marc and Bram Bresseleers \\ 2005 Messages: Sms en Chatcultuur van jongeren. Ghent: Mens en Cultuur. \\ Den Ouden, Hanny and Carel van Wijk \\ 2007 "Om vet gaaf op te kicken": over jongerentaal en het gebruik ervan in productadverten- \\ ties. Tijdschrift voor Communicatiewetenschappen 35(3): 2-20.
}


De Vogelaer, Gunther

2008 De Nederlandse en Friese subjectmarkeerders. Geografie, typologie en diachronie. Ghent: KANTL.

Grondelaers, Stefan, Dirk Geeraerts, Dirk Speelman and José Tummers

2001 Lexical standardisation in internet conversations. Comparing Belgium and The Netherlands. In: Josep M. Fontana, Louise McNally, M. Teresa Turell and Enric Vallduví (eds.), Proceedings of the First International Conference on Language Variation in Europe, 90100. Barcelona: Universitat Pompeu Fabra, Institut Universitari de Lingüística Aplicada, Unitat de Investigació de Variació Lingüística.

Kuppens, An and Annick De Houwer

2006 Van Alijs tot Zapt'em: de zelfgerapporteerde taal van Antwerpse jongeren. In: Tom Koole, Jacomine Nortier and Bert Tahitu (eds.), Artikelen van de Vijfde Sociolinguïstische Conferentie, 319-329. Delft: Eburon.

Leufkens, Sterre

2007 Sms-taal. Een linguïstische benadering. B.A. thesis, University of Amsterdam.

Sanders, Ewoud

2001 Hoest? veel suc6!: de razendsnelle opkomst van het Sms-lands. In: Onze Taal 70(6): $132-134$

Spooren, Wilbert

2009 Bezorgde ouders? De relatie tussen chat en schrijfkwaliteit. In: Wilbert Spooren, Margreet G. Onrust and José M. Sanders (eds.), Studies in Taalbeheersing 3: 331-342. Assen: Van Gorcum.

Spooren, Wilbert

2011 Wat doet sms-taal met geletterdheid? To appear in Ons erfdeel.

Tjong Kim Sang, Erik

2011 Het gebruik van Twitter voor taalkundig onderzoek. TABU 39(1/2): 62-72.

Vandekerckhove, Reinhild and Judith Nobels

2010 De standaardisatie en toe-eigening van schrijftaal. De chatcommunicatie van Vlaamse jongeren. In: Marijke van der Wal and Eep Francken (eds.), Standaardtalen in beweging, 173-192. Amsterdam: Stichting Neerlandistiek.

Van Hout, Roeland and Hans Van der Velden

2000 N-deletion in reading style. In: Helen de Hoop and Ton van der Wouden (eds.), Linguistics in the Netherlands 2000: 209-220. Amsterdam/Philadelphia: John Benjamins.

Van Oostendorp, Marc

2003 No pix, plz. Waarom taal de techniek beïnvloedt en niet andersom. In: Jan Stroop (ed.), Waar gaat het Nederlands naar toe? Panorama van een taal, 35-44. Amsterdam: Bert Bakker.

Van Wijk, Carel, Hanny den Ouden

2006 Kletsen in hiërogliefen: sms en msn-taal en het gebruik ervan in reclame. Onze taal 7/8: 195-198.

Wensveen, Sanny

2010 De Netgeneratie boeien met jongerenstijl: een succes of niet? M.A. thesis, Vrije Universiteit Amsterdam.

Willems, Annelore

2009 Het taalgebruik in sms'jes, Een (socio)linguïstisch onderzoek. M.A. thesis, Universiteit Gent. 